\title{
Geographic Distribution, Cultivar Susceptibility, and Field Observations on Bentgrass Dead Spot
}

John E. Kaminski and Peter H. Dernoeden, Department of Natural Resource Sciences and Landscape Architecture, University of Maryland, College Park 20742

\begin{abstract}
Kaminski, J. E., and Dernoeden, P. H. 2002. Geographic distribution, cultivar susceptibility, and field observations on bentgrass dead spot. Plant Dis. 86:1253-1259.

Bentgrass dead spot (BDS) is a disease of creeping bentgrass incited by Ophiosphaerella agrostis. This project was designed to determine the susceptibility of field-grown bentgrass cultivars to BDS and to gather information regarding the geographic distribution and field conditions favoring the disease. In a field cultivar evaluation trial, all major Agrostis spp. used on golf courses, including colonial, creeping, and velvet bentgrasses, were shown to be susceptible to an isolate of $O$. agrostis. Velvet bentgrass cvs. SR7200 and Bavaria were among the most and least susceptible cultivars, respectively. Among creeping bentgrass cultivars, L-93 generally was the most susceptible and Pennlinks, Penncross, and Crenshaw were among the least susceptible. Although recovery of BDS patches in the autumn was slow, Bardot colonial bentgrass and Crenshaw, Imperial, L-93, and Penn G-6 creeping bentgrasses showed the most rapid recovery prior to winter. Variation in the virulence of isolates and the potential for races of the pathogen, however, may affect cultivar susceptibility. The disease was most commonly found on 1- to 4year-old golf greens and disease severity declined 1 to 3 years after it first appeared. BDS only was found on sand-based greens, collars, and tees and has not been observed in bentgrass grown on native soil. Between 1998 and 2001, O. agrostis was isolated from diseased leaves, roots, crowns, and stolons of creeping bentgrass and hybrid bermudagrass turf samples received from 13 states. The disease was most severe in sunny and exposed locations, especially on ridges, mounds, and slopes. In the mid-Atlantic region, BDS appeared as early as May and remained active as late as December. The disease was most active in July and August, and usually became inactive with the advent of frost in October.
\end{abstract}

Additional keywords: Ophiosphaerella herpotricha, O. korrae, O. narmari, turfgrass

Creeping bentgrass (Agrostis stolonifera L.) is a widely used turfgrass species on golf course putting greens throughout the United States. Bentgrass dead spot (BDS) is a relatively new disease of creeping bentgrass that is incited by Ophiosphaerella agrostis Dernoeden, M.P.S. Câmara, N.R. O'Neill, van Berkum et M.E. Palm (1). Three other turfgrass pathogens within the genus Ophiosphaerella are known turfgrass pathogens. $O$. herpotricha (Fr.:Fr.) J. Walker; O. korrae (J. Walker \& A.M. Smith) R.A. Shoemaker \& C.E. Babcock (= Leptosphaeria korrae J. Walker \& A.M. Smith); and $O$. narmari (J. Walker \& A.M. Smith) Wetzel, Hulbert and Tisserat $(=$ L. narmari J. Walker \& A.M. Smith) were found to cause spring dead spot of bermudagrass (Cynodon dactylon (L.) Pers.) $(3,6,12,16,19,21)$. O. herpotricha also causes spring dead spot in buffalograss (Buchlö̈ dactyloides (Nutt.)

Corresponding author: P. H. Dernoeden

E-mail: pd9@umail.umd.edu

Accepted for publication 1 July 2002.

Publication no. D-2002-0826-01R

(C) 2002 The American Phytopathological Society
Engelm.) (15). Necrotic ring spot of creeping red fescue (Festuca rubra L. subsp. rubra), Kentucky bluegrass (Poa pratensis L.), and annual bluegrass (Poa annua L.) is incited by $O$. korrae $(5,10,22)$. The three aforementioned pathogens are characterized as producing darkly pigmented hyphae on roots, but none has been reported to infect creeping bentgrass.

On creeping bentgrass maintained under low mowing heights and grown on golf course putting greens, BDS appears initially as small, reddish-brown spots approximately $1.0 \mathrm{~cm}$ in diameter that may increase to $8.0 \mathrm{~cm}$ in diameter (4). During early stages of disease development, the spots are reddish-brown or copper-colored and mimic ball-mark injury. As the disease progresses, grass in the center of the spots becomes tan, while leaves in the outer edge appear reddish-brown. Patches may be distributed throughout the putting green or localized, but the spots and patches generally do not coalesce. Sometimes the spots form depressions or pits in the putting surface. Spots recover very slowly and, in severe cases, BDS patches will not fully recover prior to winter. Laboratory studies revealed that reactivation of BDS may occur after 12 to 20 days of incubation at constant temperatures $\left(25\right.$ and $\left.30^{\circ} \mathrm{C}\right)$, which are the same temperatures that are optimum for the growth of $O$. agrostis on potato dextrose agar (8). Foliar mycelium is not observed in the field but, when diseased plants are incubated under high humidity for 3 to 5 days, a white to pale pink foliar mycelium may develop. Pseudothecia often can be found in the field on necrotic leaf, sheath, and stolon tissues.

There is little or no information regarding the relative susceptibility of bentgrass cultivars to $O$. agrostis, geographic distribution of the disease, or cultural factors associated with outbreaks of BDS. Hence, the primary objectives of this research were to determine the susceptibility of various field-grown bentgrass cultivars to $O$. agrostis, and to collect information regarding cultural factors associated with BDS outbreaks and the distribution of the disease in the United States.

\section{MATERIALS AND METHODS}

Distribution of $O$. agrostis. O. agrostis isolates from 13 states were obtained from either infected tissues (i.e., stolons, roots, mottled and bronze-colored leaves, and crowns), ascocarp tissue, or from a single ascospore (Table 1). Except as otherwise noted below, most isolates were obtained from samples sent to the University of Maryland turfgrass disease diagnostic laboratory by golf course superintendents. To obtain most isolates, infected plant tissue was sectioned into 3- to 6-mm-long pieces, surface disinfested in $0.5 \%$ sodium hypochlorite for $60 \mathrm{~s}$, and washed 3 times for $30 \mathrm{~s}$ in sterile distilled water. Tissue then was blotted dry on sterilized filter paper and placed on antibiotic water agar (AWA). The AWA was prepared by autoclaving agar at $20 \mathrm{~g} \mathrm{liter}^{-1}$ of deionized water, then adding to cooled media $\left(50^{\circ} \mathrm{C}\right)$ $0.5 \mathrm{~g}$ of benzylpenicillin (Penicillin $\mathrm{G}$, Sigma-Aldrich Co., St. Louis) and $0.5 \mathrm{~g}$ of streptomycin sulfate (Sigma-Aldrich Co.). Tissues were incubated at $25^{\circ} \mathrm{C}$ and, after 3 to 4 days, actively growing mycelium was transferred to potato dextrose agar (PDA).

Single ascospore isolates were obtained by crushing a surface-disinfested pseudothecium in $1 \mathrm{ml}$ of water in a sterile petri dish ( 60 by $15 \mathrm{~mm}$ ). The spore suspension was pipetted onto AWA and dispersed using a sterile glass rod. Petri dishes were incubated in the dark at $25^{\circ} \mathrm{C}$ for $24 \mathrm{~h}$ and ascospores were observed for germination. Using a compound microscope to identify a germinating spore, single ascospores 
were referenced by marking the bottom of the petri dish with a felt-tip marker. Mycelia of a germinated ascospore free from surrounding debris then were transferred to AWA and placed in the dark at $25^{\circ} \mathrm{C}$. After isolates were allowed to grow for 3 to 4 days, actively growing mycelia were transferred to PDA.

Cultivar susceptibility to $\boldsymbol{O}$. agrostis. This field study was conducted at the University of Maryland Paint Branch Turfgrass Research Facility in College Park, MD. In August 1999, a research putting green was constructed to United States Golf Association (USGA) specifications (18). Soil was a steam-sterilized, modified sand mix ( $97 \%$ sand, $1 \%$ silt, and $2 \%$ clay) with a $\mathrm{pH}$ of 4.9 and organic matter at 10 $\mathrm{mg} \mathrm{g}^{-1}$ of soil. The initial soil P (42 $\mathrm{kg} \mathrm{ha}^{-}$ ${ }^{1}$ ) and $\mathrm{K}\left(4 \mathrm{~kg} \mathrm{ha}^{-1}\right)$ levels were low. The site was treated with agricultural limestone $\left(\mathrm{CaCO}_{3}\right)$ at 590 and $490 \mathrm{~kg} \mathrm{ha}^{-1}$ on 19 November 1999 and 29 March 2000, respectively. Soil was tested on 21 June and 25 September 2000 and the soil $\mathrm{pH}$ in the top $2.5 \mathrm{~cm}$ had increased to 5.5 and 6.9 , respectively.

Bentgrass susceptibility to $O$. agrostis was assessed between 2000 and 2001. In all, 20 Agrostis spp., including 17 cultivars and experimental lines of creeping bentgrass (ABT-CRB-1, Backspin, BAR AS 8FUS2, BAR CB 9US3, Century, Crenshaw, Imperial, L-93, Penn A-1, Penn A-2, Penn A-4, Penn G-1, Penn G-6, Penncross, Pennlinks, Providence, and SR1119); two cultivars of velvet bentgrass (Agrostis canina L.) (Bavaria and SR7200); and Bardot colonial bentgrass (Agrostis capillaris L.) were seeded into 1.5-by-3.0-m plots on 20 September 1999. All plots were seeded with grass seed at 50 $\mathrm{kg} \mathrm{ha}^{-1}$. Following seeding, the site was lightly raked, rolled, and covered with $100 \%$ spunbonded polypropylene (Reemay Inc., Old Hickory, TN) to prevent seed from dislodging. The covers were removed after seedling emergence was noted on 28 September. During the grow-in process (September to December 1999), the area received $\mathrm{N}, \mathrm{P}$, and $\mathrm{K}$ at 196, 260, and $54 \mathrm{~kg}$ $\mathrm{ha}^{-1}$, respectively from a starter fertilizer, $\left(\mathrm{N}, \mathrm{P}_{2} \mathrm{O}_{5}\right.$, and $\mathrm{K}_{2} \mathrm{O}$ at 19,25 , and $5 \%$, respectively; The Scotts Company, Marysville, $\mathrm{OH})$. The starter fertilizer contained $4.3 \%$ ammoniacal $\mathrm{N}, 7.4 \%$ urea $\mathrm{N}, 6.3 \%$ other water-soluble $\mathrm{N}, 1.0 \%$ water insoluble $\mathrm{N}$, and $1.8 \% \mathrm{~S}$. Superphosphate $\left(0-45 \quad \mathrm{P}_{2} \mathrm{O}_{5}-0\right)$ and $\mathrm{K}_{2} \mathrm{SO}_{4}\left(0-0-50 \quad \mathrm{~K}_{2} \mathrm{O}\right)$ were the $\mathrm{P}$ and $\mathrm{K}$ sources, respectively.

Table 1. Location, cultivar, and date samples were received and date of planting of 28 creeping bentgrass and hybrid bermudagrass greens confirmed to be infected by Ophiosphaerella agrostis, 19982001

\begin{tabular}{|c|c|c|c|}
\hline \multirow[b]{2}{*}{ Golf course, state } & \multirow[b]{2}{*}{ Cultivar, blend } & \multicolumn{2}{|r|}{ Date } \\
\hline & & Received & Planted $^{\mathrm{u}}$ \\
\hline P.B. Dye G.C., MD ${ }^{v}$ & Penn G-2 & Aug. 1998 & Apr.-June 1998 (se) \\
\hline Lowe's Island Club, VA ${ }^{w}$ & Pennlinks & Sept. 1998 & Autumn 1997 (se) \\
\hline Beechtree G.C., MD & L-93 + Crenshaw & Oct. 1998 & Aug.-Sept. 1997 (se) \\
\hline Ocean City G.\&Y.C., MD & Penncross & Oct. 1998 & June 1997 (se) \\
\hline Hayfields C.C., MD & L-93 + Crenshaw & Oct. 1998 & Autumn 1997 (se) \\
\hline Sand Ridge C.C., OH & L-93 & Oct. 1998 & Summer 1997 (se) \\
\hline Marlton G.C., MD & L-93 + Crenshaw & Oct. 1998 & Oct. 1997 (se) \\
\hline Hampshire Greens G.C., MD & Providence & Nov. 1998 & Oct. 1996 (se) \\
\hline Skokie G.C., IL ${ }^{x, y}$ & SR 1119 & Dec. 1998 & Sept. 1996 (se) \\
\hline Hartefeld National G.C., PA & Crenshaw + Southshore & Dec. 1998 & Sept.-Nov. 1994 (se) \\
\hline Texas A\&M University, TX & Champion & June 1999 & Summer 1997 (sp) \\
\hline Trenton C.C., NJ & L-93 & June 1999 & Nov. 1998 (sd) \\
\hline Scotch Meadows G.C., NC & Penncross & June 1999 & Aug. 1998 (se) \\
\hline Persimmon Woods G.C., MO & Penn G-2 & July 1999 & Sept. 1997 (se) \\
\hline Rutgers University, NJ & L-93 & July 1999 & Nov. 1998 (se) \\
\hline River Bend G.C., MA & L-93 & July 1999 & June 1997 (se) \\
\hline Bulle Rock G.C., MD & L-93 & Aug. 1999 & June 1997 (se) \\
\hline The Bridges G.C., PA & Penncross & Aug. 1999 & Summer 1994 (se) \\
\hline Honeybrook G.C., PA & L-93 & Nov. 1999 & Apr.-June 1999 (se) \\
\hline Inniscrone C.C., PA & L-93 + SR1020 + Providence & Mar. 2000 & Autumn 1997 (se) \\
\hline Orchard Creek G.C., NY & L-93 & Aug. 2000 & Sept. 1998 (se) \\
\hline Red Hawk G.C., MI & Providence & Sept. 2000 & Autumn 1998 (se) \\
\hline Atlantic City C.C., NJ & Penn A-4 & Sept. 2000 & Sept. 1999 (se) \\
\hline Glen View Club, $\mathrm{IL}^{\mathrm{x}, \mathrm{y}}$ & SR1119 + L-93 + Providence & Dec. 2000 & Sept. 1999(se) \\
\hline Olympia Fields C.C., IL ${ }^{\mathrm{x}, \mathrm{y}}$ & L-93 & Dec. 2000 & Sept. 1999 (se) \\
\hline Kelly Plantation G.C., FL & TifDwarf & Apr. 2001 & July-Sept. 1998 (sp) \\
\hline Mountain Branch G.C., MD & L-93 & July 2001 & Sept. 2000 (se) \\
\hline Blue Mash G.C., MD & Penn A-4 & Aug. 2001 & Sept. 2000 (se) \\
\hline
\end{tabular}

u Seeded (se); sodded (sd); sprigged (sp).

${ }^{\vee}$ G.C. = Golf Course; C.C. = Country Club; G.\&Y.C. = Golf \& Yacht Club; FL = Florida, IL = Illinois, MA = Massachusetts, MD = Maryland, MI = Michigan, MO = Missouri, NC = North Carolina, $\mathrm{NJ}=$ New Jersey, $\mathrm{OH}=$ Ohio, $\mathrm{PA}=$ Pennsylvania, $\mathrm{TX}=$ Texas, and VA = Virginia .

${ }^{w}$ Disease also found on Penncross tees seeded in 1997 and 1998.

${ }^{x}$ Area fumigated with methyl bromide prior to seeding.

y Isolated by Randy Kane, University of Illinois.

${ }^{\text {z }}$ Isolated by Henry Wetzel, North Carolina State University.
In 2000, plots received $\mathrm{N}$ at $159 \mathrm{~kg} \mathrm{ha}^{-1}$ from urea between 15 May and 27 September 2000. The final fertilizer application was made with $\mathrm{N}$ at $24 \mathrm{~kg} \mathrm{ha}^{-1}$ using the aforementioned starter fertilizer on 3 November 2000. On 27 April 2001, plots received $\mathrm{N}$ at $49 \mathrm{~kg} \mathrm{ha}^{-1}$ from the starter fertilizer and, in addition, $\mathrm{S}$ at $12 \mathrm{~kg} \mathrm{ha}^{-1}$ and $\mathrm{K}$ at $29 \mathrm{~kg} \mathrm{ha}^{-1}$ from $\mathrm{K}_{2} \mathrm{SO}_{4}$. The area was treated with foliar applications of low rates of water-soluble fertilizers $(\mathrm{N}$ at 5 to $6 \mathrm{~kg} \mathrm{ha}^{-1}$ ) approximately every 1 to 3 weeks with either urea, ammonium phosphate, or potassium nitrate between 17 May and 13 August 2001. During this period (i.e., 17 May to 13 August 2001) the area received $\mathrm{N}$ at $76 \mathrm{~kg} \mathrm{ha}^{-1}, \mathrm{P}$ at $34 \mathrm{~kg}$ $\mathrm{ha}^{-1}$, and $\mathrm{K}$ at $41 \mathrm{~kg} \mathrm{ha}^{-1}$. Starter fertilizer was applied as $\mathrm{N}$ at $24 \mathrm{~kg} \mathrm{ha}^{-1}$ on 4 and 12 September 2001. The final fertilizer application in 2001 was made with $\mathrm{N}$ at $49 \mathrm{~kg}$ $\mathrm{ha}^{-1}$ from urea. Micronutrients applied to the area between 19 June and 13 August 2001 included boron, calcium, copper, iron, magnesium, manganese, molybdenum, sulfur, and zinc and totaled 0.084, $0.846,0.359,2.44,1.16,1.16,0.004,5.62$, and $0.391 \mathrm{~kg} \mathrm{ha}^{-1}$, respectively. All fertilizers were applied either with a $\mathrm{CO}_{2}$ pressurized $(262 \mathrm{kPa})$ sprayer equipped with an 8010 flat fan nozzle calibrated to deliver water at 407 liter $\mathrm{ha}^{-1}$ or with a rotary spreader. The site was irrigated immediately following fertilizer applications with at least $1.3 \mathrm{~cm}$ of water. Micronutrients were foliar applied and were not watered in.

Plots initially were mowed on 21 October 1999 to a height of $12.5 \mathrm{~mm}$ using a walk-behind greens mower (Toro 500; Toro Inc., Minneapolis, MN) and the mowing height gradually was lowered to 9.5 $\mathrm{mm}$ by 7 December 1999. Mowing resumed 27 March 2000, and the height of cut was gradually lowered to $5.1 \mathrm{~mm}$ beginning on 17 May. In 2001, mowing was resumed on 3 April, and the height of cut was lowered and maintained between 4.0 and $4.6 \mathrm{~mm}$. The area was vertical mowed using a Toro 1000 walk-behind mower equipped with a groomer on 25 May and 10 June 2000. A sand topdressing (i.e., dried construction mix) at approximately $2,000 \mathrm{~kg} \mathrm{ha}^{-1}$ was applied on 15 December 1999 and 29 March, 5 April, 3 and 22 June, and 21 August 2000. On 18 April 2001, the entire area was aerated to a depth of $10 \mathrm{~cm}$ using a Ryan GA 30 (Textron Golf, Turf and Specialty Products, Augusta, GA) equipped with 1.3-cm-diameter hollow tines and top-dressed with dried construction mix at approximately $10,000 \mathrm{~kg} \mathrm{ha}^{-1}$. Thereafter, applications of topdressing $\left(2,000 \mathrm{~kg} \mathrm{ha}^{-1}\right)$ were made on 25 and 31 May and 8 June 2001 and the area was aerated as previously described on $16 \mathrm{Au}-$ gust 2001.

On 12 June 2000, all plots were inoculated with tall fescue (Festuca arundinacea Schreb.) seed and wheat (Triticum aesti- 
vum L.) bran infested with $O$. agrostis isolate OpVA-1. The single spore isolate was obtained in 1998 from a Pennlinks creeping bentgrass putting green at Lowe's Island Club located in Sterling, VA. The medium was prepared by soaking tall fescue seed in tap water overnight. Watersoaked seed were rinsed three times in tap water, drained, and mixed with an equal volume of wheat bran. Approximately 500 $\mathrm{ml}$ of mix then was placed in 1-liter flasks, and autoclaved for $1 \mathrm{~h}$ on two consecutive days. Mycelia from the edge of an actively growing colony on PDA were removed and placed on top of the cooled seed-bran mix. Flasks then were stored in a growth chamber under constant fluorescent light (88 $\mu \mathrm{mol} \mathrm{m} \mathrm{m}^{-2} \mathrm{~s}^{-1}$ from four F20T12/CW, 20W bulbs; Philips Lighting, Somerset, NJ) at $25^{\circ} \mathrm{C}$ for 75 days. Inoculum was mixed weekly to provide aeration and to allow mycelia to become evenly distributed throughout the medium. A small hole (approximately $1 \mathrm{~cm}$ in diameter) was created in the turf canopy using a screwdriver and approximately $0.5 \mathrm{~g}$ of inoculum was placed at the turf-soil interface. Inoculum was placed $0.6 \mathrm{~m}$ apart in the center of each plot for a total of four inoculation points per plot.

Fungicides were used to control Microdochium patch (Microdochium nivale (Fr.) Samuels and I. C. Hallett), which was active in the site in late spring of 2000. Therefore, on 2 June, a single application of chlorothalonil (Daconil Ultrex; Syngenta Crop Protection Inc., Greensboro, NC) at $9.2 \mathrm{~kg}$ a.i. $\mathrm{ha}^{-1}$ plus iprodione (Chipco 26GT; Aventis Environmental Science, Montvale, NJ) at $9.2 \mathrm{~kg}$ a.i. $\mathrm{ha}^{-1}$ was applied prior to inoculating with $O$. agrostis on 12 June 2000. In 2001, triadimefon (Bayleton; Bayer Corporation, Kansas City, MO) at $2.4 \mathrm{~kg}$ a.i. $\mathrm{ha}^{-1}$; fenarimol (Rubigan; Dow AgroSciences LLC, Indianapolis, IN) at $1.6 \mathrm{~kg}$ a.i. $\mathrm{ha}^{-1}$; propamocarb (Banol; Aventis Environmental Science) at $2.0 \mathrm{~kg}$ a.i. $\mathrm{ha}^{-1}$; tebuconazole (Lynx; Bayer Corporation) at $0.8 \mathrm{~kg}$ a.i. $\mathrm{ha}^{-1}$; flutolanil (ProStar; Aventis Environmental Science) at $2.7 \mathrm{~kg}$ a.i. $\mathrm{ha}^{-1}$; and chlorothalonil at $4.7 \mathrm{~kg}$ a.i. $\mathrm{ha}^{-1}$ were applied on 4 May, 29 June, 13 and 24 July, 13 August, and 11 September, respectively. The propamocarb was applied as a preventive treatment for Pythium blight (Pythium spp.), whereas all other treatments targeted dollar spot (Sclerotinia homoeocarpa F. T. Bennett) and brown patch (Rhizoctonia solani Kühn). With the exception of chlorothalonil (applied 11 September), all fungicides applied in 2001 were chosen based on tests that showed they had little impact on $\operatorname{BDS}(17,20)$. To control sod webworm (Crambus spp.) and black cutworm (Agrostis ipsilon Hufnagel), chlorpyrifos (Dursban, Dow AgroScience LLC) at $5.7 \mathrm{~kg}$ a.i. $\mathrm{ha}^{-1}$, fluvalinate (Mavrik Aquaflow; Sandoz Agro Inc., Des Plains, IL) at $0.08 \mathrm{~kg}$ a.i. $\mathrm{ha}^{-1}$, and chlorpyrifos at $6.7 \mathrm{~kg}$ a.i. $\mathrm{ha}^{-1}$ were applied on 8 May, 1 August, and 15 September, respectively. Wetting agents were applied as needed to control localized dry spot between 20 June and 1 August 2001. Wetting agent applications included either Aqueduct (50\% nonionic polyols; Aquatrols, Inc, Cherry Hills, NJ), Primer (95\% polymeric polyoxyalkylenes, 5\% oxoalkenyl hydroxy polyoxylakane diyl; Aquatrols, Inc) or LescoWet Flowable (2-butoxyethanol, polyoxyethylene, polypropoxypropanol; Lesco, Inc.,
Sebring, FL) at 6.2 liter $\mathrm{ha}^{-1}$. Granular products were applied with a rotary spreader, while all sprayable materials were applied through a $\mathrm{CO}_{2}$-pressurized sprayer as described previously.

The experimental design was a randomized complete block with four replications. $O$. agrostis infection centers were counted, and data from each year were used to determine the area under the disease progress curve (AUDPC). The AUDPC values were calculated using the formula $\Sigma\left[\left(y_{i}+y_{i}+\right.\right.$ $\left.\left.{ }_{1}\right) / 2\right]\left(t_{i+1}-t_{i}\right)$, where $i=1,2,3 \ldots \mathrm{n}-1, y_{i}$ is the number of BDS infection centers, and $t_{i}$ is the date of the $i$ th rating (2). The AUDPC data then were standardized by dividing the AUDPC value by the total time duration $\left(t_{\mathrm{n}}-t_{i}\right)$ of the experiment. The AUDPC values represent the total disease $\times$ days, but standardized AUDPC data are unitless (7). The dates used to calculate the AUDPC were collected between 8 August and 29 November 2000 and from 15 May to 17 September 2001. All data for individual rating dates and AUDPC values were transformed using the formula $x=(y+0.5)^{1 / 2}(14)$. Data were analyzed using the SAS MIXED procedure and means were separated based on Fisher's least significant difference test $(P$ $\leq 0.05$ ).

BDS field observations and survey. Disease progress at various golf courses was monitored by visits, a mail survey, telephone calls, or by e-mail with the superintendents between 1999 and 2001. In February 2000 and 2001, a survey was sent to superintendents of golf courses diagnosed with BDS between 1998 and 2000 (Table 2). Survey information regarding BDS was collected from 21 different golf

Table 2. Soil mixture, $\mathrm{pH}$, and dates of active bentgrass dead spot (BDS) symptoms at 21 golf courses surveyed, 2000-2001

\begin{tabular}{|c|c|c|c|c|}
\hline \multirow[b]{2}{*}{ Golf course, state ${ }^{y}$} & \multicolumn{2}{|l|}{ Soil mixture $^{w}$} & \multicolumn{2}{|c|}{ Active period $^{x}$} \\
\hline & sand/organic matter (vol/vol) & pH & Month & Year \\
\hline Atlantic City C.C., NJ & $85 / 15$ & 5.9 & Sept.-Nov. & 2000 \\
\hline Beechtree G.C., MD & $85 / 15$ & 6.2 & Aug.-Dec. & 1998-2000 \\
\hline Bulle Rock G.C., MD & $80 / 20$ & 6.2 & June-Aug. & 1999 \\
\hline Glen View Club, IL ${ }^{z}$ & $\ldots$ & $\ldots$ & Aug.-Oct. & 2000 \\
\hline Hampshire Greens G.C., MD & $90 / 10$ & 5.0 & July-Oct. & 1998 \\
\hline Hartefeld National G.C., PA & $85 / 15$ & 4.9 & July-Sept. & 1998-2000 \\
\hline Hayfields C.C., MD & & 6.0 & May-Nov. & 1998-2000 \\
\hline Honeybrook G.C., PA & $90 / 10$ & 5.8 & June-Oct. & 1999-2000 \\
\hline Inniscrone C.C., PA & $85 / 15$ & 5.2 & June-Oct. & 1999-2000 \\
\hline Lowe's Island Club, VA & $90 / 10$ & 5.1 & Aug.-Dec. & 1998-1999 \\
\hline Marlton G.C., MD & $85 / 15$ & 6.8 & July-Dec. & 1998 \\
\hline Ocean City G.\&Y.C., MD & $85 / 15$ & 5.0 & Aug.-Oct. & 1998-2000 \\
\hline Olympia Fields C.C., IL ${ }^{z}$ & $\ldots$ & 7.2 & July-Nov. & 2000 \\
\hline Orchard Creek G.C., NY & $87 / 13$ & 7.6 & July-Sept. & 2000 \\
\hline P.B. Dye G.C., MD & $100 / 0$ & 6.9 & June-Sept. & 1998-2000 \\
\hline Persimmon Woods G.C., MO & $80 / 20$ & 6.5 & May-Nov. & 1999-2000 \\
\hline Red Hawk G.C., MI & $100 / 0$ & 7.8 & Aug.-Sept. & 2000 \\
\hline River Bend G.C., MA & $85 / 15$ & 6.2 & June-Oct & 1999 \\
\hline Sand Ridge C.C., OH & $80 / 20$ & 7.0 & July-Sept. & 1998-2000 \\
\hline The Bridges G.C., PA & $80 / 20$ & 5.8 & July-Oct. & 1998-2000 \\
\hline Trenton C.C., NJ & $80 / 20$ & 5.8 & May-July & 1999 \\
\hline
\end{tabular}

${ }^{\mathrm{w}} \ldots=$ information not provided.

${ }^{x}$ Period when active BDS symptoms were evident.

y G.C. $=$ Golf Course; C.C. $=$ Country Club; G.\&Y.C. $=$ Golf \& Yacht Club; IL = Illinois, MA = Massachusetts, MD = Maryland, MI = Michigan, MO = Missouri, NJ = New Jersey, OH = Ohio, PA = Pennsylvania, and VA = Virginia.

${ }^{\mathrm{z}}$ Soil fumigated with methyl bromide prior to seeding. 
courses in 10 states as follows: Illinois $(n=$ 2), Massachusetts $(n=1)$, Maryland $(n=$ 7), Michigan $(n=1)$, Missouri $(n=1)$, New Jersey $(n=2)$, New York $(n=1)$, Ohio $(n=1)$, Pennsylvania $(n=4)$, and Virginia $(n=1)$. Reactivation of BDS as well as new outbreaks and weather conditions surrounding the outbreaks were noted. This survey was intended to collect information regarding soil characteristics, cultivar or cultivars used, and other factors that may have influenced BDS incidence and severity. A timeline of BDS severity was developed based on the initial disease outbreak and disease severity in consecutive years.

\section{RESULTS AND DISCUSSION}

Distribution of $\boldsymbol{O}$. agrostis. In all, 42 isolates of $O$. agrostis were obtained from creeping bentgrass or hybrid bermudagrass golf greens $(n=28)$ in Illinois $(n=3)$, Florida $(n=1)$, Maryland $(n=9)$, Massachusetts $(n=1)$, Michigan $(n=1)$, Missouri $(n=1)$, New Jersey $(n=3)$, New York $(n=1)$, North Carolina $(n=1)$, Ohio $(n=1)$, Pennsylvania $(n=4)$, Texas $(n=$ $1)$, and Virginia $(n=1)$ (Table 1, Fig. 1). All isolates were determined to be $O$. agrostis based on the presence of pseudothecia in samples or the rose-quartz color of colonies as described by Câmara et al. (1) and Dernoeden et al. (4).

1998. In 1998, 15 isolates from 10 golf courses were obtained from Illinois $(n=1)$, Maryland $(n=6)$, Ohio $(n=1)$, Pennsylvania $(n=1)$, and Virginia $(n=1)$. Planting date and the month each sample was received are shown in Table 1 . BDS generally developed within 1 to 2 years following seeding. An exception occurred at Hartefeld National Golf Course (G.C.), Pennsylvania, where the greens were

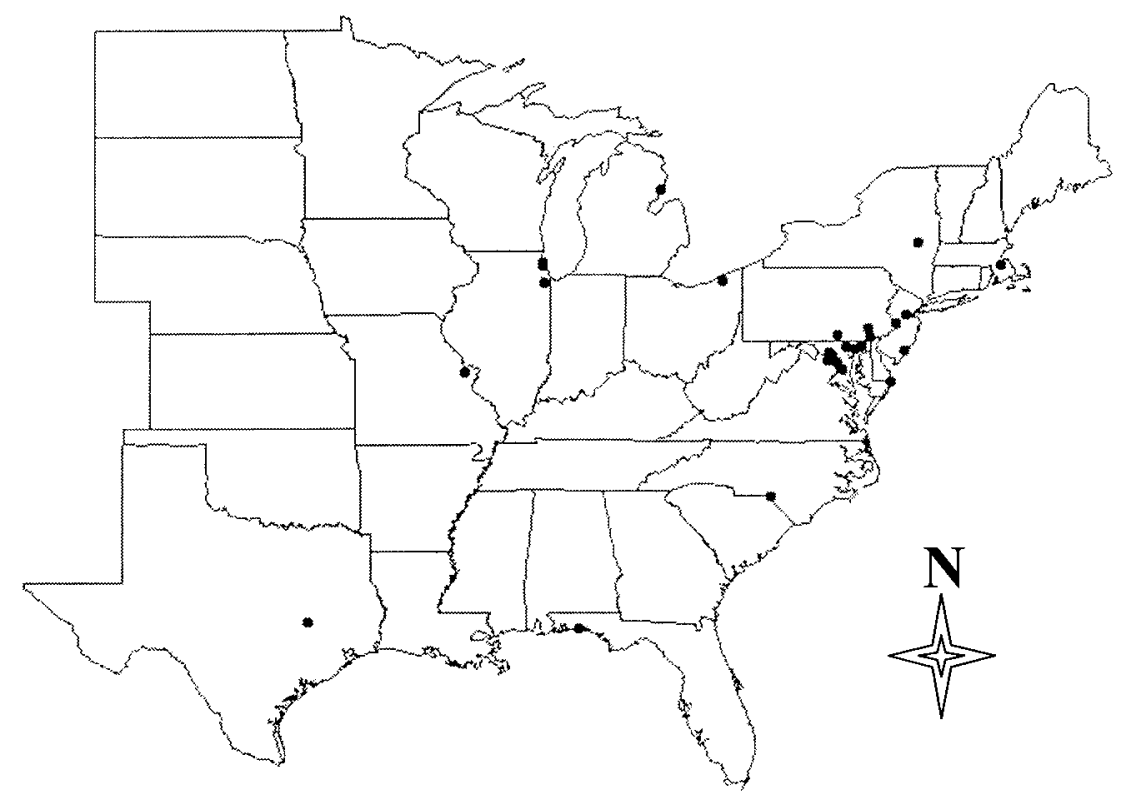

Fig. 1. Location of creeping bentgrass and bermudagrass greens confirmed to be infected by Ophiosphaerella agrostis in the United States, 1998-2001. seeded in autumn 1994, but BDS was not noted until 1998. Except for the sample from Sand Ridge Country Club (C.C.), Ohio (seeded summer 1997), all BDS samples received in 1998 contained numerous pseudothecia. Although no pseudothecia were found in the BDS sample from Ohio, the pathogen was isolated from a bentgrass stolon. After growing the isolate on PDA on a lab bench for several weeks, a single pseudothecium containing septate ascospores developed. This was the only time a isolate from Skokie G.C., Illinois (received from R. Kane) was the first reported case of BDS developing on a green that had been fumigated with methyl bromide prior to seeding.

1999. O. agrostis was isolated on 4 June 1999 from hybrid bermudagrass (Cynodon dactylon (L.) Pers. $\times$ C. transvaalensis Burtt-Davy) plants. The Champion bermudagrass sample sent by R. White was from a research green at Texas A\&M University, which was sprigged in 1997 and overseeded with roughstalk bluegrass ( $\mathrm{Poa}$ trivialis L.) in 1997 and 1998. Numerous pseudothecia with mature ascospores were found embedded in leaves and stolons. Single-ascospore isolates were obtained from pseudothecia and one isolate was obtained from the roots. The occurrence of $O$. agrostis infection of bermudagrass in Texas subsequently was reported by Krausz et al. (9), and the disease was named bermudagrass dead spot.

Between mid-June and August 1999, several new outbreaks of BDS occurred in bentgrass greens in the eastern and Midwestern United States. Creeping bentgrass samples from Trenton C.C., New Jersey (sodded November 1998); Rutgers University Turfgrass Research Facility, New Jerpseudothecium was produced on PDA. The sey (seeded November 1998); Persimmon Woods G.C., Missouri (seeded September 1997); River Bend C.C., Massachusetts (seeded June 1997); Bulle Rock G.C, Maryland (seeded June 1997); and Honeybrook G.C., Pennsylvania (seeded April to June 1999) were diagnosed with BDS (Table 1). O. agrostis also was isolated from 5-year-old creeping bentgrass putting greens at The Bridges G.C., Pennsylvania (seeded summer 1994). According to the superintendent, BDS first appeared in 1998 and disease symptoms remained visible into 2000 (Table 2). The North Carolina isolate (received from $\mathrm{H}$. Wetzel), was obtained from Scotch Meadows G.C., North Carolina, which was from a green seeded in August 1998 following fumigation with methyl bromide. Unlike 1998, most diseased samples received in 1999 did not contain pseudothecia.

2000. In March 2000, diseased samples were received from Inniscrone C.C., Pennsylvania (seeded autumn 1997) and $O$. agrostis was isolated from a pseudothecium and from leaf tissue (Table 1). According to the golf course superintendent, BDS became active at Inniscrone C.C. in August 1999. In August 2000, O. agrostis was isolated from bronze-colored leaves of creeping bentgrass from Orchard Creek G.C., New York (seeded in September 1998). The pathogen also was isolated from creeping bentgrass seeded in the autumn of 1998 at Red Hawk G.C., Michigan. In September 2000, O. agrostis was isolated from creeping bentgrass seeded 1 year prior at Atlantic City C.C., New Jersey. According to the golf course superintendents, BDS appeared on greens at Glen View Club, Illinois and Olympia Fields C.C., Illinois in July 2000. Both Illinois isolates (received from R. Kane) were from greens that were fumigated with methyl bromide in September 1999.

2001. In April 2001, O. agrostis was isolated from a discolored stolon node of Tifdwarf bermudagrass. The sample was from a green at Kelly Plantation G.C., Florida (sprigged July to September 1998). In 2001, the disease was confirmed from creeping bentgrass samples obtained from Mountain Branch G.C., Maryland and Blue Mash G.C., Maryland. Both bentgrass greens were seeded in September of 2000, and the pathogen was isolated from each course in July and August 2001, respectively. Pseudothecia containing immature ascospores were found in the sample from Blue Mash G.C. In addition, O. agrostis again was isolated from Honeybrook G.C.

The pathogen was isolated from leaves, roots, crowns, and stolons, demonstrating that $O$. agrostis attacks all creeping bentgrass tissues. Infected leaves generally were reddish-brown or bronze-colored. Unlike previous reports $(1,4)$, dark-brown hyphae were observed on creeping bentgrass stolons. In particular, dark-brown to black hyphal masses congregated near or 
on the nodes of stolons, but generally were absent in the internode region. Occasionally, brown to black "runner" hyphae were observed in the internode region of bentgrass stolons and on roots adjacent to the stem base of infected plants or the nodes of infected stolons. Hyphae on these roots generally were found at the point of root emergence and did not appear to extend more than a few millimeters down the length of individual roots.

Cultivar susceptibility to $\boldsymbol{O}$. agrostis. BDS data were collected between 8 August and 29 November 2000 and 15 May and 17 September 2001. The data were transformed, but the pretransformed means are shown. Significant differences among cul-

Table 3. Analysis of variance for the number of bentgrass dead spot infection centers per plot on individual rating dates and the area under the disease progress curve (AUDPC) for 20 field-grown Agrostis spp. cultivars and experimental lines, College Park, MD, 2000 and $2001^{\mathrm{z}}$

\begin{tabular}{lcl}
\hline Rating date & Type III F & Pr $>\boldsymbol{F}$ \\
\hline 2000 & & \\
8 August & 3.54 & $* * *$ \\
6 September & 3.03 & $* *$ \\
8 November & 4.75 & $* * *$ \\
29 November & 5.67 & $* * *$ \\
AUDPC & 4.48 & $* * *$ \\
2001 & & \\
15 May & 5.29 & $* * *$ \\
18 June & 5.29 & $* * *$ \\
24 July & 1.24 & NS \\
16 August & 1.83 & $*$ \\
17 September & 1.54 & NS \\
AUDPC & 5.34 & $* * *$
\end{tabular}

${ }^{\mathrm{z}}$ Not significant (NS); *, **, and $* * *=$ significant at $P \bullet 0.05,0.001$, and 0.0001 , respectively. tivars were found on all rating dates except 24 July and 17 September 2001 (Table 3).

In 2000, all cultivars showed BDS symptoms and, by 8 August, the number of infection centers (spots) per plot for each cultivar averaged between 4 for Bavaria and 23 for SR7200 velvet bentgrasses (Table 4). Although SR7200 had the greatest number of spots per plot, there were no significant differences among SR7200 and L-93, Imperial, Providence, Penn G-1 or A-1, and ABT-CRB-1 creeping bentgrasses on 8 August. Initially, Bavaria velvet and Crenshaw creeping bentgrasses had the fewest spots, but there were no significant differences in the number of spots among the aforementioned cultivars and Backspin, Pennlinks, and BAR AS 8US3 on 8 August. Except for SR7200, the greatest number of BDS spots per plot for all cultivars occurred on 6 September. Although few significant differences were present, the cultivar L-93 had the greatest number of infection centers on 6 September. With few exceptions, all cultivars had begun to recover by 8 November. The number of BDS infection centers per plot for SR7200, however, had increased slightly on 8 November, but a reduction in the number of spots was observed on 29 November. Complete recovery of the dead spots did not occur for any cultivar by the time bentgrass growth slowed in late November. Total disease (as indicated by AUDPC values) was greatest for SR7200, but AUDPC values were not significantly different from those of L-93, Penn A-1 and A-4, Imperial, and Bardot. Bavaria exhibited the lowest AUDPC values for the year, which were similar to AUDPC values for Pennlinks, Penncross, and Crenshaw.
BDS exhibited little to no new activity in 2001 (data not shown). There were no differences in the number of BDS infection centers among the cultivars in July or September and the differences observed in August were minimal. Recovery was slow and a few dead spots were still evident on 17 September. The AUDPC values for 2001 generally were representative of the initial spring levels of disease remaining from the previous season (Table 4). Lowest and highest AUDPC values again were observed in Bavaria and SR7200, respectively.

These data revealed that $O$. agrostis is capable of infecting the common Agrostis species and cultivars grown on golf courses. Individual cultivars within a species showed varying levels of susceptibility. The velvet bentgrass cvs. SR7200 and Bavaria generally were the most and least susceptible, respectively. Bardot colonial bentgrass was highly susceptible to BDS, but exhibited the greatest amount of recovery prior to winter. The creeping bentgrass cultivars exhibited varying levels of susceptibility and recovery. Among the creeping bentgrass cultivars, L-93 had the greatest number of infection centers during the period of highest disease pressure (6 September 2000), but the number of infection centers was not significantly different from most other creeping bentgrass cultivars, including Penn A-1, A-4, G-1, G-6, Imperial, ABT-CRB-1, and Providence. Pennlinks, Penncross, and Crenshaw had BDS levels that were not significantly different from the least susceptible cultivar (Bavaria) on 6 September 2000, and generally were the least susceptible creeping bentgrass cultivars.

Table 4. Bentgrass dead spot infection centers and area under the disease progress curve (AUDPC) values for 20 field-grown Agrostis spp. cultivars and experimental lines, College Park, MD, 2000 and 2001

\begin{tabular}{|c|c|c|c|c|c|c|c|c|}
\hline \multirow[b]{3}{*}{ Cultivar } & \multirow[b]{3}{*}{ Bentgrass spp. } & \multicolumn{5}{|c|}{ Infection centers per plot ${ }^{y}$} & & \\
\hline & & \multicolumn{4}{|c|}{2000} & \multirow{2}{*}{$\begin{array}{c}2001 \\
15 \text { May }\end{array}$} & \multicolumn{2}{|c|}{$\mathbf{A U D P C}^{\mathbf{z}}$} \\
\hline & & 8 Aug & 6 Sept & 8 Nov & 29 Nov & & 2000 & 2001 \\
\hline$\overline{\text { ABT-CRB-1 }}$ & Creeping & $14 \mathrm{a}-\mathrm{d}$ & $27 \mathrm{a}-\mathrm{d}$ & $18 \mathrm{bc}$ & $11 \mathrm{~b}-\mathrm{e}$ & 9 bcd & $21 \mathrm{bc}$ & $5 \mathrm{bc}$ \\
\hline Backspin & Creeping & $7 \mathrm{~d}-\mathrm{g}$ & 18 cde & $9 \mathrm{gh}$ & $6 \mathrm{fgh}$ & $6 \mathrm{cde}$ & $12 \mathrm{de}$ & $3 \mathrm{~d}-\mathrm{h}$ \\
\hline BAR AS 8US3 & Creeping & $6 \mathrm{fg}$ & $21 \mathrm{~b}-\mathrm{e}$ & $12 \mathrm{c}-\mathrm{g}$ & $7 \mathrm{~d}-\mathrm{h}$ & 7 bcd & 14 cde & $3 c-g$ \\
\hline BAR CB 8FUS2 & Creeping & $10 \mathrm{~b}-\mathrm{f}$ & $22 \mathrm{~b}-\mathrm{e}$ & $19 \mathrm{bc}$ & $10 \mathrm{~b}-\mathrm{e}$ & $11 \mathrm{ab}$ & $18 \mathrm{bcd}$ & $4 \mathrm{~b}-\mathrm{e}$ \\
\hline Bardot & Colonial & $10 \mathrm{~b}-\mathrm{f}$ & $32 \mathrm{ab}$ & $17 \mathrm{~b}-\mathrm{e}$ & $6 \mathrm{e}-\mathrm{h}$ & $4 \mathrm{ef}$ & $21 \mathrm{abc}$ & $2 \mathrm{hi}$ \\
\hline Bavaria & Velvet & $4 \mathrm{~g}$ & $8 \mathrm{f}$ & $6 \mathrm{~h}$ & $4 \mathrm{~h}$ & $2 \mathrm{f}$ & $6 \mathrm{f}$ & $1 \mathrm{i}$ \\
\hline Century & Creeping & $11 \mathrm{~b}-\mathrm{f}$ & $27 \mathrm{a}-\mathrm{d}$ & 18 bcd & $14 \mathrm{bc}$ & $11 \mathrm{ab}$ & $21 \mathrm{bc}$ & $4 b-f$ \\
\hline Crenshaw & Creeping & $4 \mathrm{~g}$ & 17 def & $10 \mathrm{e}-\mathrm{h}$ & $5 \mathrm{gh}$ & $6 \mathrm{de}$ & 12 ef & 2 ghi \\
\hline Imperial & Creeping & $16 a b c$ & $33 a b$ & $16 \mathrm{~b}-\mathrm{f}$ & $9 \mathrm{c}-\mathrm{g}$ & 8 bcd & $22 \mathrm{abc}$ & $3 \mathrm{e}-\mathrm{h}$ \\
\hline L-93 & Creeping & $16 a b$ & $37 \mathrm{a}$ & $19 \mathrm{bc}$ & 11 bcd & $10 \mathrm{abc}$ & $25 \mathrm{ab}$ & 5 bcd \\
\hline Penn A-1 & Creeping & $15 \mathrm{a}-\mathrm{d}$ & $33 \mathrm{ab}$ & $22 \mathrm{~b}$ & $15 \mathrm{bc}$ & $11 \mathrm{ab}$ & $25 \mathrm{ab}$ & $6 \mathrm{~b}$ \\
\hline Penn A-2 & Creeping & $12 \mathrm{~b}-\mathrm{f}$ & $23 \mathrm{~b}-\mathrm{e}$ & $13 \mathrm{c}-\mathrm{g}$ & $8 d-h$ & 8 bcd & 16 cde & $4 \mathrm{~b}-\mathrm{f}$ \\
\hline Penn A-4 & Creeping & $13 \mathrm{bcd}$ & $29 \mathrm{a}-\mathrm{d}$ & $19 \mathrm{bc}$ & $15 \mathrm{~b}$ & $12 \mathrm{ab}$ & $22 \mathrm{abc}$ & $5 \mathrm{~b}-\mathrm{f}$ \\
\hline Penn G-1 & Creeping & $14 \mathrm{a}-\mathrm{d}$ & $25 \mathrm{a}-\mathrm{e}$ & $14 \mathrm{~b}-\mathrm{g}$ & $10 \mathrm{~b}-\mathrm{f}$ & $8 \mathrm{bcd}$ & $18 \mathrm{~b}-\mathrm{e}$ & $4 b-g$ \\
\hline Penn G-6 & Creeping & $11 \mathrm{~b}-\mathrm{e}$ & $29 \mathrm{abc}$ & $14 \mathrm{~b}-\mathrm{g}$ & $8 \mathrm{~d}-\mathrm{h}$ & 9 bcd & $19 \mathrm{bc}$ & $4 \mathrm{~b}-\mathrm{g}$ \\
\hline Penncross & Creeping & $8 \mathrm{c}-\mathrm{f}$ & 14 ef & $11 \mathrm{~d}-\mathrm{g}$ & $6 \mathrm{e}-\mathrm{h}$ & 7 bcd & $11 \mathrm{def}$ & $3 c-g$ \\
\hline Pennlinks & Creeping & 6 efg & $17 \mathrm{def}$ & $9 \mathrm{fgh}$ & $7 \mathrm{~d}-\mathrm{h}$ & $5 \mathrm{de}$ & $12 \mathrm{def}$ & $3 \mathrm{fgh}$ \\
\hline Providence & Creeping & $15 \mathrm{abc}$ & $24 \mathrm{a}-\mathrm{e}$ & $14 \mathrm{c}-\mathrm{g}$ & $11 \mathrm{~b}-\mathrm{e}$ & $11 \mathrm{ab}$ & $18 \mathrm{~b}-\mathrm{e}$ & $4 \mathrm{~b}-\mathrm{f}$ \\
\hline SR1119 & Creeping & $11 \mathrm{~b}-\mathrm{f}$ & $22 \mathrm{~b}-\mathrm{e}$ & $16 \mathrm{~b}-\mathrm{f}$ & $10 \mathrm{~b}-\mathrm{f}$ & $11 \mathrm{ab}$ & $17 \mathrm{~b}-\mathrm{e}$ & $5 \mathrm{~b}-\mathrm{e}$ \\
\hline SR7200 & Velvet & $23 \mathrm{a}$ & $32 \mathrm{ab}$ & $35 \mathrm{a}$ & $24 \mathrm{a}$ & $14 \mathrm{a}$ & $31 \mathrm{a}$ & $9 \mathrm{a}$ \\
\hline
\end{tabular}

${ }^{\mathrm{z}}$ Means in a column followed by the same letter are not significantly different $(P \leq 0.05)$ based on Fisher's least significant difference test.

${ }^{y}$ Data were transformed $(y+0.5)^{1 / 2}$, but pretransformed means are shown.

${ }^{z}$ Data used to calculate AUDPC values were collected between 8 August and 29 November 2000 and from 15 May to 17 September 2001. 
Recovery of BDS patches was slow and did not begin to occur until after 6 September 2000. Little recovery from BDS occurred between the final rating date in 2000 (29 November) and 15 May 2001 (Table 4). Once bentgrass growth decreased in late autumn, little to no recovery occurred and spots remained evident until growth resumed in late spring. Recovery was most apparent during late spring and early summer. Recovery of all cultivars from BDS probably was enhanced by the applications of $\mathrm{N}$ at 49 and $24 \mathrm{~kg} \mathrm{ha}^{-1}$ on 27 September and 3 November 2000, respectively. In 2001, BDS levels were considerably less and new infections were minimal. Most infection centers from 2000 continued to recover, but new disease activity was observed in several previously infected spots between June and September 2001. The reason for decreased BDS activity in 2001 is unknown. Decline in BDS activity may be attributed to the buildup of antagonistic soil microorganisms, maturation of the turf, variable environmental conditions, or the cultural practices and the chemicals employed.

BDS field observations and survey. According to the survey, a few different methods were used to construct the golf greens, but all greens consisted of at least $80 \%$ sand as the primary soil medium. All new greens were constructed to either USGA specifications $(n=17)$, California $(n=1)$, or push-up style $(n=1)$ using onsite sand. In addition, two older golf courses (Glen View Club and Olympia Fields C.C.) were renovated using methyl bromide, but had a sand-based medium from several years of topdressing. While a great deal of site information was collected from the survey, some notable observations are described below.

Although BDS generally developed between 1 and 2 years following bentgrass establishment, outbreaks of BDS were observed on creeping bentgrass that was less than 1 year old and as old as 6 years of age (Table 2). With few exceptions, BDS was most severe during the first or second year of symptom expression and declined as the greens aged. The decline phase generally lasted anywhere from 1 to 3 years after the first year of disease expression, with the number of infection centers per green normally decreasing in subsequent years. A few golf courses, however, noticed an increase in disease severity on greens that were not infected in the previous year. Although BDS was observed primarily on the putting surfaces, occasionally it was found on sand-based bentgrass collars and tees, indicating that $O$. agrostis can attack creeping bentgrass maintained at higher (i.e., $>0.2 \mathrm{~mm}$ ) mowing heights. The occurrence of BDS on primarily young or methyl bromide-fumigated greens, but not on greens older than 6 years of age, suggests that BDS declines rapidly. BDS was not found in fairways or other sites where bentgrass was grown on native soil. These observations support the premise that the pathogen may be most damaging where soil microbial populations are low; however, the inoculum potential at the site may have been too low to incite disease in the second year. A similar decline occurs with take-all (Gaeumannomyces graminis (Sacc.) Arx and D. Olivier var. avenae (E. M. Turner) Dennis) in Agrostis turf in response to a build-up of bacterial antagonists $(11,13)$. BDS activity was observed as early as May, but generally was most active during the summer and early autumn months (Table 2). Recovery of BDS patches was slow, and active spots often remained evident until the first hard frost. In 1998, however, active BDS patches were observed as late as midDecember at Lowe's Island Club.

Few observations on fungicide efficacy were reported in either survey. Field fungicide evaluation trials reported by Towers et al. (17) and Wetzel (20) showed that propiconazole (Banner MAXX; Syngenta Crop Protection, Inc.), chlorothalonil, thiophanate methyl (Clearys 3336; Cleary Chemical Corporation, Dayton, NJ), fludioxonil (Medallion; Syngenta Crop Protection, Inc.), and iprodione effectively controlled BDS, but little or no control was provided by triadimefon, trifloxystrobin (Compass; Bayer Corporation), mefenoxam (Subdue MAXX; Syngenta Crop Protection, Inc.), or a formulation of Bacillus subtilis.

Active BDS infection centers generally appeared in areas with full sun and good air circulation and disease severity varied from a few spots to several hundred per green. In a few instances (i.e., Glen View Club, Atlantic City C.C., Hayfields C.C., Inniscrone C.C., Olympia Fields C.C., and P. B. Dye G.C.), less severe BDS outbreaks were found on partially shaded greens. In addition, many superintendents observed that $O$. agrostis infection centers occurred predominantly along ridges and on mounds and south-facing slopes of greens. These areas are particularly prone to higher soil temperatures and often are the first to exhibit drought symptoms. The aforementioned conditions generally result in higher levels of plant stress and may reduce the defense capabilities of creeping bentgrass.

Among the surveyed golf courses, soil $\mathrm{pH}$ ranged from 4.9 to 7.8 (Table 2). The dates and methods used to measure soil $\mathrm{pH}$ at each site were not determined. Hence, these data provide no conclusive information on the importance of soil $\mathrm{pH}$ on BDS incidence and severity. A few superintendents reported that applying small amounts of water-soluble $\mathrm{N}$ (at 5 to $6 \mathrm{~kg} \mathrm{ha}^{-1}$ ) with each fungicide application helped to reduce BDS severity and aided in bentgrass recovery. According to Wetzel (20), weekly applications of urea in conjunction with fungicides reduced BDS infection centers. When applied weekly, however, urea alone did not significantly reduce BDS severity when compared with the untreated control (20).

In summary, BDS was found in creeping bentgrass as far north as Michigan, as far west as Missouri, and along the eastern seaboard of the United States from Massachusetts to North Carolina. In addition, $O$. agrostis was found in Texas and Florida, causing dead spots in hybrid bermudagrass greens that had been overseeded with roughstalk bluegrass. Survey reports confirmed that $O$. agrostis was found causing disease in numerous creeping bentgrass cultivars, including Crenshaw, L-93, Penn A-4, Penn G-2, Penncross, Pennlinks, Providence, Southshore, SR1020, and SR1119. Of the 28 different golf courses from which $O$. agrostis was isolated, 14 had grown L-93 in monostands or in blends. Cultivar evaluation trials showed that all major Agrostis spp. used on golf courses were susceptible to BDS. Over the course of the study, SR7200 and Bavaria were shown to be among the most and least susceptible cultivars, respectively. L93, however, was among the most susceptible creeping bentgrass cultivars. It is important to note that only a single isolate was used to inoculate plots in this study, and that different races of the pathogen may exist in nature. Variation in virulence among $O$. agrostis isolates and the potential for different races could result in varying levels of disease severity among bentgrass cultivars. The disease was most commonly found on greens within 2 years following the seeding of new greens or older greens that had been fumigated with methyl bromide. Field observations confirm that the disease may decline dramatically within 1 to 3 years. The oldest greens where BDS was found, however, were 6 years old. BDS has been found only on sand-based greens, collars, and tees, and has not been found in bentgrass or bermudagrass grown on native soil. The disease also was introduced on L-93 washed sod. Based on the timing that samples were received in 1998 (late August through December), the disease initially was thought to be a problem during late summer and autumn months (4). Results of the survey and other observations confirmed that the disease was most prevalent in July and August, but may appear in May and can remain active in bentgrass as late as December. Disease symptoms in bermudagrass, however, appeared as early as March in Florida.

\section{ACKNOWLEDGMENTS}

We thank the United States Golf Association for providing financial support for this study, R. Kane and H. Wetzel for providing isolates, and all of the golf course superintendents who contributed information.

\section{LITERATURE CITED}

1. Câmara, M. P. S, O’Neill, N. R., van Berkum, P., Dernoeden, P. H., and Palm, M. E. 2000. Ophiosphaerella agrostis sp. nov. and its rela- 
tionship to other species of Ophiosphaerella. Mycologia 92:317-325.

2. Campbell, C. L., and Madden, L. V. 1990. Introduction to Plant Disease Epidemiology. John Wiley and Sons, New York.

3. Crahay, J. N., Dernoeden, P. H., and O'Neill, N. R. 1988. Growth and pathogenicity of Leptosphaeria korrae in bermudagrass. Plant Dis. 72:945-949.

4. Dernoeden, P. H., O'Neill, N. R., Câmara, M. P. S, and Feng, Y. 1999. A new disease of Agrostis palustris incited by an undescribed species of Ophiosphaerella. Plant Dis. 83:397.

5. Dernoeden, P. H., Zhang, M., and Wetzel, H. C. 1995. First report of necrotic ring spot (Leptosphaeria korrae) in creeping red fescue in Maryland. Plant Dis. 79:966.

6. Endo, R. M., Ohr, H. D., and Krausman, E. M. 1985. Leptosphaeria korrae, a cause of the spring dead spot disease of bermudagrass in California. Plant Dis. 69:235-237.

7. Fry, W. E. 1977. Integrated control of potato late blight: Effects of polygenic resistance and techniques of timing fungicide applications. Phytopathology 68:1650-1655.

8. Kaminski, J. E., Dernoeden, P. H., O’Neill, N. R., and Momen, B. Reactivation of bentgrass dead spot and growth, pseudothecia produc- tion and ascospore germination of Ophiosphaerella agrostis. Plant Dis. In press.

9. Krausz, J. P., White, R. H., Foerster, W., Tisserat, N. A., and Dernoeden, P. H. 2001. Bermudagrass dead spot: A new disease of bermudagrass caused by Ophiosphaerella agrostis. Plant Dis. 85:1286.

10. Landschoot, P. J. 1996. First report of necrotic ring spot on Poa annua putting greens in Pennsylvania. Plant Dis. 80:712.

11. Smiley, R. W., Dernoeden, P. H., and Clarke B. B. 1992. Pages 57-58 in: Compendium of Turfgrass Diseases. The American Phytopathological Society Press, St. Paul, MN.

12. Smith, A. M. 1965. Ophiobolus herpotrichus a cause of spring dead spot in couch turf. Agric. Gaz. N. S. W. 76:753-758.

13. Smith, J. D., Jackson, N., and Woolhouse, A. R. 1989. Pages 137-146 in: Fungal Diseases of Amenity Turf Grasses. E. \& F. N. Spon, New York.

14. Steele, R. G., and Torrie, J. J. 1980. Principles and Procedures of Statistics: A Biometrical Approach. 2nd ed. McGraw-Hill, New York.

15. Tisserat, N., Wetzel, H. C., Fry, J., and Martin, D. L. 1999. Spring dead spot of buffalograss caused by Ophiosphaerella herpotricha in Kansas and Oklahoma. Plant Dis. 83:199.

16. Tisserat, N. A., Pair, J. C., and Nus, A. 1989.
Ophiosphaerella herpotricha, a cause of spring dead spot of bermudagrass in Kansas. Plant Dis. 73:933-937.

17. Towers, G. W., Majumdar, P. R., Weibel, E. N., Frasier, C. L., Vaiciunas, J. N., Peacos, M. and Clarke, B. 2000. Evaluation of chemical and biological fungicides for the control of bentgrass dead spot in creeping bentgrass. Rutgers Turfgrass Proc. 2000 32:211-215.

18. United States Golf Association Green Section Staff. 1993. USGA recommendations for a method of putting green construction. USGA Green Sect. Record 31(2): 1-3.

19. Walker, J., and Smith, A. M. 1972. Leptosphaeria narmari and L. korrae spp. nov., two long-spored pathogens of grasses in Australia. Trans. Br. Mycol. Soc. 58:459-466.

20. Wetzel, H. C. 2000. Evaluation of fungicides and urea for the control of bentgrass dead spot in an 'L-93' putting green in Raleigh, NC, 1999. Fungic. Nematic. Tests 55:510

21. Wetzel, H. C., Hulbert, S. H., and Tisserat, N. A. 1999. Molecular evidence for the presence of Ophiosphaerella narmari n. comb., a cause of spring dead spot of Bermuda grass, in North America. Mycol. Res. 103:581-589.

22. Worf, G. L., Stewart, J. S., and Avenius, R. C. 1986. Necrotic ring spot disease of turfgrass in Wisconsin. Plant Dis. 70:453-458. 